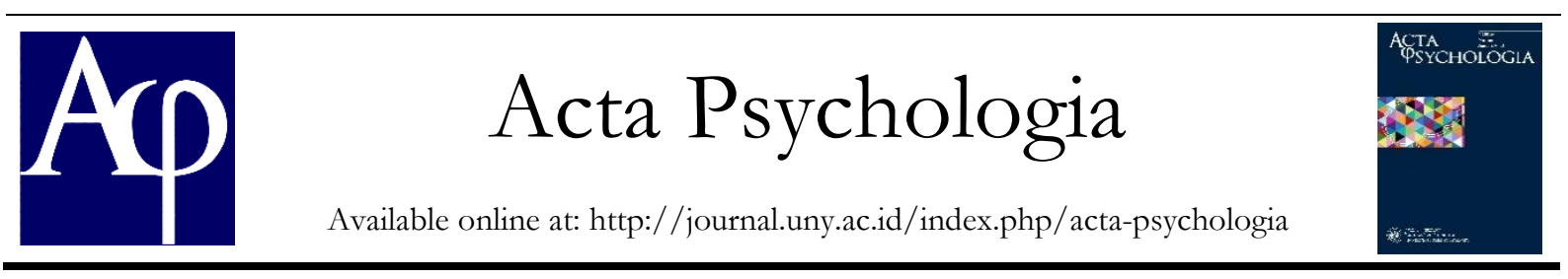

\title{
Regulasi Emosi dan Kecemasan pada Petugas Pemadam Kebakaran
}

\author{
Rosa Tiara Kusuma \\ Program Studi Psikologi, Universitas Negeri Yogyakarta; Jl. Colombo No. 1 Sleman Yogyakarta, \\ 55281 \\ rosatiaraksm98@gmail.com
}

\begin{abstract}
Abstrak
Penelitian ini bertujuan untuk melihat hubungan antara regulasi emosi dan kecemasan pada anggota pemadam kebakaran di Kabupaten Bantul. Penelitian ini menggunakan pendekatan kuantitatif dengan jenis penelitian deskripsi korelasi. Subjek penelitian ini adalah seluruh petugas pemadam kebakaran yang berada di Kabupaten Bantul berjumlah 66 orang, 1 induk dan 3 pos pemadam kebakaran di beberapa kecamatan, yang berada di bawah naungan BPBD Kabupaten Bantul. Instrumen penelitian ini menggunakan dua skala yaitu skala regulasi emosi ERQ (Emotion Regulation Quastionnaire) yang terdiri dari 10 item dengan reliabilitas sebesar 0,811 dan skala kecemasan STAI (State-Trait Anxiety Inventory) yang terdiri dari 40 item yaitu 20 item formulir Y-1 (state anxiety) dengan reliabilitas sebesar 0,910 dan 20 item formulir Y-2 (trait anxiety) dengan reliabilitas sebesar 0,925. Hasil analisis data menggunakan Pearson Product Moment menunjukkan terdapat hubungan negatif antara regulasi emosi dan kecemasan pada anggota pemadam kebakaran di Kabupaten Bantul, dengan nilai korelasi sebesar $-0,515$ dan signifikansi $\mathrm{p}<0,05$ artinya semakin rendah kemampuan regulasi emosi maka semakin tinggi tingkat kecemasan petugas pemadam kebakaran di Kabupaten Bantul, begitu pula sebaliknya.
\end{abstract}

Kata Kunci: regulasi emosi, kecemasan, risiko kerja, pemadam kebakaran

\begin{abstract}
The purpose of this study was to examine the relationship between emotional regulation and anxiety in firefighters in Bantul Regency. This study used a quantitative approach with correlation design. The subjects of this research were 66 firefighters in Bantul Regency, 1 main unit and 3 fire stations in several sub-districts, which are under the auspices of the Bantul Regency BPBD. This research instrument used two scales namely the ERQ emotion regulation scale consisting of 10 items with a reliability of 0.811 and the anxiety scale STAI (State-Trait Anxiety Inventory) consisting of 40 items namely 20 items of Y-1 form (state anxiety) with a reliability of 0.910 and 20 items of the Y-2 form (trait anxiety) with a reliability of 0.925 . The results of data analysis using Pearson Product Moment which shows a negative relationship between registration and debate about firefighters in Bantul District, with an estimated value of $-0,515$ and a significance of $\mathrm{p}<0.05$, which means it is easier to conduct related negotiations so as to increase the amount affordable fire department in Bantul Regency, and vice versa
\end{abstract}

Keywords: emotion regulation, anxiety, work risk, firefighters

\section{Pendahuluan}

Setiap kegiatan atau pekerjaan yang dilakukan setiap individu memiliki risiko mulai dari rendah sampai tinggi. Petugas pemadam kebakaran merupakan salah satu pekerjaan dengan risiko tinggi. Berbagai macam risiko mulai dari api yang bisa menyebabkan terbakar bila terkena bagian tubuh, lemas karena kurangnya oksigen, pingsan, iritasi mata, luka bakar ditangan atau kaki, terkena sengatan besi dan seng, terkena reruntuhan alat rumah tangga seperti almari, genteng, lapisan tembok. Ada pula yang mengalami kecelakaan kerja dikarenakan tertiban reruntuhan kayu atap. Aini (2016) mengatakan bahwa ketika terjadi kebakaran, asap yang menggumpal berwarna hitam dapat mengakibatkan gangguan pada sistem pernapasan walaupun 
sudah memakai masker khusus. Selain itu tingginya karbon monoksida akan mengakibatkan rendahnya oksigen sehingga akan terjadi perubahan pada pernapasan, nadi, dan tekanan darah.

Keluhan kesehatan yang dirasakan petugas pemadam kebakaran di lokasi kebakaran umumnya dikarenakan banyak menghirup asap misalnya batuk, sesak nafas, mual, muntah, pusing, mata perih bahkan pingsan. Paparan risiko pada petugas pemadam kebakaran merupakan bahaya potensial yang meliputi bahaya fisik, bahaya kimia, bahaya listrik, bahaya mekanik dan bahaya biologi. Penglihatan juga akan terganggu dikarenakan kepulan asap dan api yang mengakibatkan kemerahan pada mata. Kejadian yang tidak diduga juga sangat bisa terjadi seperti tertimpa reruntuhan bangunan dan terjebak dalam kebakaran.

Di tengah risiko besar yang harus dihadapi, grafik terjadinya kebakaran di wilayah Kabupaten Bantul terus meningkat dari tahun ke tahun. Hal ini berdampak pada meningkatnya frekuensi petugas pemadam kebakaran terpapar kondisi berisiko. Data BPBD dari tahun 2010 sampai 2016 dengan kasus kebakaran total keseluruhan kejadian ada 426 kejadian kebakaran (bpbd.bantulkab.go.id). Badan Penanggulangan Bencana Daerah (BPBD) Kabupaten Bantul mencatat pada tahun 2018 sampai pada bulan September sudah ada 116 kasus kejadian kebakaran. Jumlah ini mengalami peningkatan cukup signifikan dibandingkan tahun sebelumnya (tribunjogja.com). BPBD Kabupaten Bantul mencatat pada tahun 2019 sampai bulan September terjadi peningkatan kasus kebakaran hingga mencapai 149 kasus kebakaran (tribunjogja.com). Pemadam kebakaran adalah salah satu bidang pekerjaan yang mungkin mempertaruhkan keselamatan hidup karena pekerjaan ini adalah salah satu pekerjaan yang beresiko tinggi (Kompas.com).

Petugas Pemadam kebakaran (Damkar) adalah orang atau pasukan yang bertugas memadamkan kebakaran, melakukan penyelamatan, dan menanggulangi bencana atau kejadian lainnya. Dampak yang terjadi jika rasa aman seorang petugas pemadam kebakaran tidak terpenuhi, yaitu dapat mengakibatkan kecelakaan kerja, cedera fisik akibat kecelakaan, kondisi psikis yang tertekan, gelisah, cemas, tertekan dengan keadaan yang ada, bahkan bisa sampai kehilangan nyawa.

Beberapa hal sebelum proses pemadaman berlangsung, petugas pemadam kebakaran yang menerima laporan terjadinya kebakaran dituntut untuk sigap, siap, cepat, dan tanggap dalam menghadapi laporan kebakaran. Dalam waktu yang singkat dan cepat harus segera sampai pada lokasi tujuan kebakaran untuk melaksanakan tugasnya memadamkan api. Dalam proses penerimaan laporan hingga sampai lokasi tujuan hanya ada waktu 15 menit. Petugas pemadam kebakaran memerlukan persiapan dari segi fisik, peralatan pemadaman, dan psikis. Petugas pemadam kebakaran harus memiliki kondisi stamina yang baik dan sehat serta kondisi emosi yang baik pula. Dalam kondisi seperti ini petugas pemadam kebakaran rentan mengalami cemas karena terkejut. Kecemasan yang dialami petugas pemadam kebakaran menimbulkan perilaku yang berbeda pada setiap individu meskipun tingkat kecmasannya beragam.

Ada beberapa petugas pemadam kebakaran pada saat merasakan cemas akan menunjukkan perilaku yang gugup, takut, tegang, dan teledor. Dampak yang terjadi petugas pemadam kebakaran menjadi lalai pada peralatan pemadaman yang harus mereka pakai, karena terburu-buru dan cemas, beberapa lupa untuk tidak memakai peralatan secara lengkap. Perilaku lain yang kerap muncul adalah pikiran dan perilaku tidak sinkron.

Hal-hal tersebut yang menambah risiko petugas pemadam kebakaran menjadi dua kali lipat dan tidak jarang jika performa petugas pemadam kebakaran kurang 
maksimal. Sedangkan ada petugas pemadam kebakaran yang merasakan cemas pada saat menerima laporan, namun waktu pemadaman berlangsung mereka bisa menyelesaikan tugas dan menunjukkan performa dengan baik serta tidak membahayakan diri karena memakai peralatan secara lengkap sesuai standar pemadaman.

Marsh (2015) menyebutkan bahwa kecemasan ialah suatu perasaan yang tidak tenang, gelisah, takut, dan khawatir. Kecemasan meliputi emosi dan sensasi fisik yang dialami seorang individu saat gugup atau khawatir akan suatu hal. Petugas Pemadam kebakaran memerlukan ketenangan untuk menyikapi dan menghadapi kecemasan karena suatu laporan kejadian kebakaran atau bencana alam. Untuk mengelola kecemasan tersebut, pemadam kebakaran perlu memiliki pengelolaan emosi yang baik. Untuk dapat mengelola emosi yang baik, diperlukan kemampuan regulasi emosi (Gross \& Thompson, 2014). Kemampuan regulasi emosi yaitu suatu kemampuan yang dimiliki seorang individu untuk menilai, mengelola, mengatasi dan mengungkapkan emosi yang tepat untuk mencapai keseimbangan emosional. Jika seorang individu memiliki kemampuan tersebut maka dapat mengatasi ketegangan dalam hidupnya (Mayangsari \& Ranakusuma, 2014).

Penelitian ini didukung dengan penelitian yang telah ada atau telah dilakukan sebelumnya beberapa penelitian yang relevan dengan penelitian ini adalah penelitian Mayangsari \& Ranakusuma (2014) berjudul "Hubungan Regulasi Emosi Dan Kecemasan Pada Petugas Penyidik Polri Dan Penyidik PNS" dengan kesimpulannya yaitu semakin tinggi kecemasan sesaat yang dialami oleh Penyidik, maka semakin rendah kecenderungan reappraisal dalam meregulasi emosi. Aprisandityas \& Elfida (2012) berjudul "Hubungan Antara Regulasi Emosi Dan Kecemasan Pada Ibu Hamil" dengan simpulan terdapat hubungan yang signifikan antara regulasi emosi dengan kecemasan pada ibu hamil, semakin baik kemampuan regulasi emosi ibu hamil maka semakin rendah kecemasan yang dirasakan. Sulistyo (2015) berjudul "Hubungan Antara Regulasi Emosi Dan Kecemasan Menghadapi Pertandingan" dengan kesimpulan bahwa semakin tinggi regulasi emosi maka semakin rendah kecemasan menghadapi pertandingan, begitu juga sebaliknya. Dari beberapa hasil riset sebelumnya menghubungkan antara regulasi emosi dan kecemasan individu.

Penelitian ini bertujuan untuk mengetahui hubungan regulasi emosi dan kecemasan pada petugas pemadam kebakaran di Kabupaten Bantul. Penelitian ini diharapkan dapat memberikan manfaat di bidang psikologi yaitu mengenai regulasi emosi dan kecemasan pada petugas pemadam kebakaran. Selain itu, penelitian ini diharapkan dapat memperkaya penelitian di bidang psikologi industri dan organisasi, sehingga hasil penelitian ini nantinya dapat dijadikan sebagai bahan penunjang penelitian lainnya yang berkaitan dengan Kecemasan dan Regulasi Emosi. Serta dapat menjadi masukan dan informasi yang berkaitan dengan regulasi emosi dan kecemasan pada petugas pemadam kebakaran.

\section{Metode Penelitian}

\section{Jenis penelitian}

Penelitian ini dengan menggunakan pendekatan kuantitatif korelasi. Desain dalam penelitian ini adalah desain penelitian deskripsi korelasi. Adapun tujuannya yaitu menggambarkan dan menjelaskan kejadian secara general dari sampel ke populasi.

\section{Waktu dan tempat penelitian}

Penelitian dilakukan di Kantor Badan Penanggulangan Bencana Daerah Kabupaten Bantul yang berfokus pada Petugas Pemadam Kebakaran di Jalan Cepit, Palbapang, Bantul, Bantul, Daerah 
Istimewa Yogyakarta. Pemadam kebakaran adalah bidang pekerjaan yang memiliki 1 induk dan 3 pos pemadam kebakaran di beberapa kecamatan, yang berada dibawah naungan BPBD Kabupaten Bantul. Waktu penelitian dilakukan sejak Februari 2019.

\section{Subjek Penelitian}

Penelitian ini merupakan penelitian populasi karena melibatkan satu populasi saja dengan subjek penelitian yaitu petugas pemadam kebakaran di Kabupaten Bantul sebanyak 66 orang.

\section{Teknik pengumpulan data dan instrumen}

Teknik pengumpulan data dalam penelitian ini menggunakan kuesioner. Skala yang digunakan dalam penelitian ini mengadopsi dari ahli yaitu skala regulasi emosi ERQ (Emotion Regulation Quastionnaire) dari Gross \& John (2003) dan mengadopsi skala kecemasan STAI (State-Trait Anxiety Inventory) dari Spielberger (2004).

\section{Teknik Analisis data}

Teknik analisis data menggunakan Uji Korelasi Product-moment (Pearson) yang bertujuan untuk menguji hipotesis asosiatif (uji hubungan) dua variabel. Sebelum uji korelasi peneliti melakukan uji prasyarat Test for Linearity pada taraf signifikansi 0,05. Dua variabel dikatakan mempunyai hubungan yang linear bila signifikansi (Linearity) kurang dari 0,05

\section{Hasil Penelitian dan Pembahasan \\ Karakteristik subjek}

Penelitian dilakukan di Kantor Badan Penanggulangan Bencana Daerah Kabupaten Bantul yang berfokus pada Petugas Pemadam Kebakaran di Jalan Cepit, Palbapang, Bantul, Bantul, Daerah Istimewa Yogyakarta. Pemadam kebakaran adalah bidang pekerjaan yang memiliki 66 anggota aktif, 1 induk dan 3 pos pemadam kebakaran di beberapa kecamatan, yang berada dibawah naungan BPBD Kabupaten Bantul. Dengan pengambilan responden sebanyak 66 responden yang terdiri dari 3 perempuan dan 63 laki-laki.

Tabel 1. Data demografi subjek

\begin{tabular}{lll}
\hline Kategori & Jumlah & Presentase \\
\hline Jenis Kelamin & & \\
Laki-Laki & 63 & $95,5 \%$ \\
Perempuan & 3 & $4,5 \%$ \\
\hline Status Pernikahan & & \\
Menikah & 40 & $61 \%$ \\
Belum Menikah & 26 & $39 \%$ \\
\hline Pendidikan Terakhir & & \\
SMA/SMK & 59 & $89 \%$ \\
S1 & 7 & $11 \%$ \\
\hline Usia & & \\
$18-20$ & 5 & $8 \%$ \\
$21-30$ & 37 & $56 \%$ \\
$31-40$ & 15 & $23 \%$ \\
$41-50$ & 6 & $9 \%$ \\
$51-60$ & 3 & $5 \%$ \\
\hline
\end{tabular}

Petugas Pemadam kebakaran, lebih banyak yang sudah menikah daripada yang belum menikah. Pendidikan terakhir petugas pemadam kebakaran didominasi SMA/SMK, dengan demikian sedikit pendidikan S1. Usia pada petugas pemadam kebakaran paling banyak pada usia 21-40 tahun.

\section{Hasil data deskriptif}

Tabel 2. Statistik deskriptif regulasi emosi dan kecemasan

\begin{tabular}{lcc}
\hline & $\begin{array}{c}\text { Regulasi } \\
\text { Emosi }\end{array}$ & Kecemasan \\
\hline mean & 57,53 & 93,54 \\
median & 57 & 93 \\
modus & 55 & 94 \\
stdv & 3,49 & 4,26 \\
skor min & 51 & 82 \\
skor max & 69 & 101 \\
\hline
\end{tabular}

Tabel di atas menunjukkan skor regulasi emosi berkisar dari 51 hingga 69 dengan rata-rata skor sebesar 57.53. Adapun skor kecemasan berkisar dari 82 hingga 101 dengan rata-rata sebesar 93.54. 


\section{Hasil uji korelasi}

Sebelum dilakukan uji korelasi, peneliti melakukan uji prasyarat linieritas. Hasil dari uji linearitas untuk variabel regulasi emosi dan kecemasan 0,136 > 0,05 maka terdapat hubungan yang linear antara dua variabel. Setelah terbukti memiliki hubungan yang linier, peneliti melakukan pengujian korelasi. Hasil uji korelasi Product-moment dari Pearson antara regulasi emosi dan kecemasan yaitu sebesar -0.525 dengan signifikansi $<0,05$ yang berarti regulasi emosi dan kecemasan memiliki korelasi. Ketentuan kuat dan lemahnya suatu hubungan menurut Pearson adalah 0,811,00 sempurna 0,61-0,80 kuat, 0,41-0,60 sedang, 0,21-0,40 lemah, dan 0,00-0,20 tidak ada. Dengan demikian besarnya korelasi termasuk dalam kategori sedang.

Gambar 1. Grafik korelasi regulasi emosi dan kecemasan

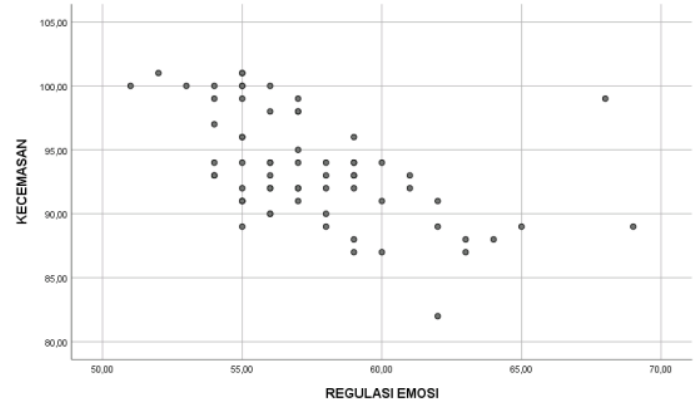

Dari gambar 1, regulasi emosi dan kecemasan memiliki hubungan negative. Grafik menunjukkan pola hubungan linear antara kedua variabel dan terdapat korelasi serta pada grafik cenderung ke kekiri atas.

\section{Pembahasan}

Hasil dari penelitian ini menunjukkan bahwa terdapat hubungan negatif antara variabel regulasi emosi dan variabel kecemasan. Pola hubungan linear dalam kategori sedang antara variabel regulasi emosi dan variabel kecemasan. Grafik menunjukkan bahwa terdapat korelasi dan cenderung kekiri (negatif).
Pada petugas pemadam kebakaran semakin rendah kemampuan anggota pemadam kebakaran untuk melakukan regulasi emosi maka semakin tinggi kecemasan. Petugas pemadam kebakaran mengalami kecemasan pada saat akan atau sedang melaksanakan tugasnya memadamkan kebakaran dan menghadapi bencana. Kecemasan yang tinggi akan membuat petugas pemadam kebakaran kehilangan fokus dan konsentrasi yang mengakibatkan keteledoran dan kecelakaan dalam bekerja. Petugas pemadam kebakaran mengalami kecemasan dikarenakan peran tuntutan pekerjaan yang mengharuskan untuk sigap, cepat, dan tanggap dalam waktu yang terbatas untuk menangani kebakaran. Hal tersebut yang membuat petugas pemadam kebakaran mengalami kecemasan. Dalam hal ini petugas pemadam kebakaran melakukan pengelolaan emosi untuk menekan atau mengurangi kecemasan yang dirasakan dengan caranya. Petugas pemadam kebakaran yang dapat mengelola emosi dengan baik maka akan memiliki performa yang baik dalam mengatasi kebakaran.

\section{Simpulan dan saran \\ Simpulan}

Berdasarkan hasil penelitian, dapat ditarik kesimpulan bahwa variabel regulasi emosi dan variabel kecemasan memiliki hubungan negatif. Pada pemadam kebakaran semakin rendah kemampuan regulasi emosi pada anggota pemadam kebakaran maka semakin tinggi kecemasan yang dialami. Berdasarkan analisis maka hipotesis penelitian ini dapat diterima.

\section{Saran}

Berdasar hasil penelitian yang diperolej, peneliti menyarankan beberapa hal. Pertama. petugas pemadam kebakaran untuk mempertahankan pengelolaan emosi agar dapat menekan atau mengurangi kecemasan yang dirasakan pada saat 
melaksanakan tugas dan mengelola kecemasan yang dirasakan. Kedua, perlunya ahli yang berkompeten dalam bidang psikologi untuk membantu meningkatkan psikoedukasi anggota pemadam kebakaran yang mengalami trauma kecelakaan kerja atau kecemasan dalam pekerjaannya sebagai anggota pemadam kebakaran agar dapat membantu mengontrol anggota pemadam kebakaran baik secara fisik ataupun psikis.

\section{Daftar Pustaka}

Abderrezzag, S. (2010). The effects of anxiety on student's achievement. Disertasi, Mentouri University, tidak diterbitkan

Aini, A.N. (2016). Analisis Risiko Kerja Dan Upaya Pengendalian Bahaya Pada Petugas Pemadam Kebakaran Di Dinas Pemadam Kebakaran Kota Semarang. Fakultas Kesehatan Masyarakat Universitas Diponegoro.

Anggreiny, Nila. (2014). Rational Emotive Behavioural Therapy (REBT) Untuk Meningkatkan Kemampuan Regulasi Emosi Remaja Korban Kekerasan Seksual. (Thesis). Magistes Psikologi Profesi, Universitas Sumatera Utara.

Aprisandityas, A., \& Elfida, D. (2012) Hubungan Antara Regulasi Emosi Dengan Kecemasan Pada Ibu Hamil. Vol 8, No 2 (2012).

Arikunto, S. (2002). Prosedur Penelitian Suatu Pendekatan Praktik. Jakarta: Rineka Cipta

Arikunto, S. (2006). Metode Penelitian Kualitatif. Jakarta: Bumi Aksara

Azwar, S. (2007). Metode Penelitian. Yogyakarta: Pustaka Pelajar

Azwar, S. (2010). Metode Penelitian. Yogyakarta: Pustaka Pelajar.
Azwar, S. (2011). Reliabilitas dan Validitas.Yogyakarta: Pustaka Pelajar

Azwar, S. (2016). Penyusunan Skala Psikologi. Yogyakarta: Pustaka Pelajar

Azwar, S. (2018). Metode Penelitian Psikologi (Edisi II ed.). Yogyakarta: Pustaka Pelajar.

Bastug,G., ErgulTopcu, A., Ozel-Kizil, E.T., Ergun, O.F., (2019). Secondary Traumatization And Related Psychological Outocomes In Firefighters. Journal of Loss and Trauma.

Burgess,JL., dkk. (2018). The Firefighter Multicenter Cancer Cohort Study: Framework Development And Testing.

Creswell, J.W. (2008). Educational Research. Planing. Conducting, and Evaluating Qualitative \& Quantitative Approaches. London. Sage Publications.

Creswell, J.W. (2014). Research Design : Qualitative, Quantitative and Mixed Methods Approaches : fourth edition. Sage publications, Inc.

Creswell, Jhon W. (2016). Research Design Pendekatan Kualitatif, Kuantitatif, trimdan Mixed. Yogyakarta: Pustaka Pelajar.

Direktorat Jendral Bina Administrasi Kewilayahan Kementrian Dalam Negeri. (2015). Modul Firefighter I Yudha Brama Jaya. Universitas Indonesia.

Egloff, B., Schmukle, S.C., Burns, L.R., \& Schwerdtfeger, A. (2006). Spontaneous emotion regulation during evaluated speaking tasks: associations with negative affect, anxiety expression, memory, and physiological responding. Emorion, Vol. 6, No. 3, 356-366 
Hofmann, S.G., Heering, S., Sawyer, A.T., \& Asnaani, A. (2009). How to Handle Anxiety: The Effects of Reappraisal, Acceptancance, and Suppression Strategies on Anxious Arousal. Behav Res Ther. 47(5): 389-394

Gillespie, S. M., \& Beech, A. R. (2016). Theories of Emotion Regulation. The Wiley Handbook on the Theories, Assessment and Treatment of Sexual Offending,1, 245-263.

https://doi.org/10.1002/97811185 74003.wattso012

Gross, J.J. (1998). Antecedent and Response-Focused Emotion Regulation : Divergent Consequences for Experience, Expression, and Physiology. Stanford University. Journal of Personality and Social Psychology. 1998. Vol. 74, No. I, 224-23?

Gross, J., John, O.P., \& Eng, J. (1998). Three approaches to individual differences in affect regulation: Conceptualizations, measures, and findings. Handbook of emotion regulation (1st ed).

Gross, J. J. (1999). Emotion Regulation: Past, Present, Future. Cognition and Emotion, 13, 551- 573.

Gross, J. J. (2002). Emotion Regulation : Affective, Cognitive, and Social Consequences. Department of Psychology, Stanford University, Stanford, California, USA. Psychopsychology, 39 (2002) 281291. Cambridge University Press. Printed in the USA.

Gross, J.J. (2007). Emotion Regulation: Conseptual Foundations (Chapter 1). Handbook of Regulation Emotion. New York: Guilford Press.
Gross, J.J. (2014) Handbook of Emotional Regulation second edition, Newyork. Guilford Press. ISBN 978-1-4625-0350-6

Gross J.J \& John. (2003). Individual Differences in Two Emotion Regulation Processes: Implications for Affect, Relationships, and WellBeing. Journal of Personality and Social Psychology, 85, 348-363.

Gross, J.J.; John, O. P. (2013). Emotion Regulation Questionnaire (ERQ). Journal of Personality and Social Psychology, 85, 348-362. https://doi.org/10.1037/00223514.85.2.348

Gross, J.J., John, O. P., \& Eng, J. (2014). Three Aproaches to Individual Differences in Affect Regulation: Conceptualizations, measures, and finddings. Handbook of emotion regulation (2nd ed).

Hendrikson. (2013). Faktor-Faktor yang Mempengaruhi Emosi. Jakarta: Gramedia.

https://bpbd.bantulkab.go.id/data/kebaka ran/lihat-data/ diakses pada hari Selasa, 20 April 2019

https://jogja.tribunnews.com/2018/09/25 /hingga-september-sudah-ada-116kasuskebakaran-di-bantul./ diakses pada hari Sabtu, 29 September 2019

https://jogja.tribunnews.com/2019/09/30 / kemarau-panjang-kebakaran-dibantul-meningkat-hingga-akhirseptember-sudah-149-kasus

https://megapolitan.kompas.com/read/20 17/09/22/16464631/pekerjaanberisiko-tinggi-tunjanganpemadam-kebakaran-di-jakartaakan/ diakses pada hari Sabtu 30 November 2019

Lazarus, (1976). Pattern of Adjustment. Mc Graw Hill Inc. 
Lazarus, S. Richard. (1994). Coping with aging. Nursing Times, 93(37), 21. https://doi.org/10.1016/j.jomh.20 08.06.026

Maslow, A.H. (1984). Motivation and Personality (Teori Motivasi dengan Ancangan Hirarki Kebutuhan Manusia). Jakarta: PT. Gramedia.

Maslow, A.H. (1984). Motivation and Personality (Teori Motivasi dengan Motivasi dan Kepribadian). Yogyakarta: Cantrik Pustaka, Cet:1.

Marsh, L. (2015). Understanding Anxiety And Panic Attacks. London: Mind (National Association for Mental Health).

Mayangsari, E. D, dan Ranakusuma, O.I. (2014). Hubungan Regulasi Emosi dan Kecemasan Pada Petugas Penyidik Polri dan Penyidik PNS. Fakultas Psikologi Universitas YARSI. Jurnal Psikogenesis, Volume 3, No.1, Desember 2014.

Nevid, J.S., Rathus, S.A, \& Greene, B. (2005). Psikologi Abnormal (edisi ke lima). Jakarta: Penerbit Erlangga.

Ratnasari, S. dan Suleeman, J. (2017). Perbedaan Regulasi Emosi Perempuan danLaki-Laki di Perguruan Tinggi. Jurnal Psikologi Sosial. Vol. 15, No. 01, 35-46.

Pratama, V.F.M., (2018). Motivasi Kerja Petugas Pemadam Kebakaran. Fakultas Psikologi Universitas Muhammadiyah Malang.

Puspanagari., Egar, T., \& Purwanto, S. (2017). Hubungan Antara Regulasi Emosi Dengan Kecemasan Berbicara Di Depan Kelas. Skripsi Thesis. Universitas Muhammadiyah Surakarta.

Sentana, A.D. (2016). Analisis faktor-faktor yang mempengaruhi tingkat kecemasan keluarga pasien yang dirawat di ruang intensif care RSUD
Provinsi NTB tahun 2015. Jurnal Kesehatan Prima: 10, 1694-1708.

Smith, T.D., dkk. (2018). Assessment of relationships between work stress, work-family conflict, burnout and firefighter safety behavior outcomes. Safety Science 103.

Spielberger, C. D. (1972). Anxiety current trends in theory and research. New York: Academic Press Ltd.

Spielberger, R. K. (1996), Computer Anxiety, Sex, Race and Age. International Journal of ManMachine Studies. 25, Hal. 711-719.

Spielberger, C. D. (2004). Cross Cultural Anxiety, Universitas Michigan

Spielberger, C. D. (2004). State trait anxiety inventory STAI. Palo Alto, CA: Consulting Psychogists Press.

Sulistyo, Ery. (2015). Hubungan Antara Regulasi Emosi Dengan Kecemasan Menghadapi Pertandingan. Skripsi Thesis, Universitas Muhammadiyah Surakarta.

Thompson, R.A. (1994). Emotion Regulation: A Theme in Search of Definition. Monographs of the Society for Research in Child Development, 59, 25-52.

Wibowo, S., Amboningtyas, D., Fathoni, A., et al. (2017). Analisis Pengaruh Kebutuhan Fisiologis, Kebutuhan Keamanan, Kebutuhan Sosial, Kebutuhan Penghargaan, Kebutuhan Aktualisasi Terhadap Produktivitas Kerja Karyawan Pada Fleet Departemen di PT. Serasi Autoraya Cabang Semarang. Fakultas Ekonomi Universitas Pandanaran Semarang.

Wicaksono, A.B., \& Saufi, M. (2013). Mengelola Kecemasan Siswa Dalam Pembelajaran Matematika. Prosiding Pendidikan Matematika, ISBN: 978-979-16353-9-4,89-94. 